Editorial

\title{
Economic and Environmental Impact Assessment of Renewable Energy from Biomass
}

\author{
Jacopo Bacenetti \\ Department of Environmental Science and Policy, State University of Milan, 20133 Milano, Italy; \\ jacopo.bacenetti@unimi.it; Tel.: +39-02-503-16869
}

Received: 5 July 2020; Accepted: 7 July 2020; Published: 13 July 2020

\begin{abstract}
For a holistic evaluation of sustainability, the economic and environmental aspects should be considered jointly to avoid trade-offs between the two dimensions. In this manuscript, the themes addressed, and the approaches used in this Special Issue "Economic and Environmental Impact Assessment of Renewable Energy from Biomass" to investigate the sustainability are summarized. Different approaches such as Energy Analysis, Life Cycle Assessment, technical and economic evaluation of key processes are applied to different renewable energy pathways (biogas, wood biomass, by-product valorization, etc.). The different manuscripts accepted in this Special Issue increases our comprehension and understanding of the relation between economic and environmental performances of renewable energy from biomass.
\end{abstract}

Keywords: renewable energy; biomass; economic evaluation; environmental sustainability; life cycle assessment

\section{Introduction}

In the last years, the interest in the use of biomass for renewable energy production has steadily increased due to environmental and energy independence concerns [1]. Sustainability assessments of renewable energy technologies should certainly include analysis of the environmental impact.

However, to encourage environmentally sustainable bioenergy strategies, the analytic evaluation of the economic and environmental performance of different bioenergy solutions is needed.

For a holistic evaluation of sustainability, the economic and environmental aspects should be considered jointly to avoid trade-offs between the two dimensions. When only one aspect is considered the optimization of the performances could be achieved to the detriment of the other one.

Due to the impact related to energy generation from fossil fuel and thanks to the target of renewable energy production defined by different countries [2,3], in the last decades the interest in energy generation from biomass has increased.

Woody biomass such as an herbaceous one, and dry biomass or wet biomass can be efficiently valorized for energy purposes. In this context the biomass can be specifically produced such as Short Rotation Coppice of poplar and willow [4,5], and cereal crops such as maize, winter cereals and sorghum for biogas production [6-8] can be used. Nevertheless, the renewable energy production should be sustainable from an economic and environmental point of view. If from the economic side the achievement of satisfactory results is greatly helped by the presence of public subsidies (i.e., Fusi et al. [2] highlighted how in 29 European countries the production of renewable electricity is granted by a Feed-in-Tariff) from an environmental point of view the sustainability is strongly affected by the type of biomass and by the conversion process $[9,10]$. On the other side, it should be considered that often a trade-off among environmental impact categories exists and it is difficult to identify a mitigation solution that is able to reduce all of the environmental effects related to renewable energy production [11,12]. Furthermore, not rarely, the improvement of the environmental results requires the 
implementation of mitigation strategies that, requiring not negligible investment, negatively affect the economic results. In this regard, in the last year more and more studies performed a joint assessment of economic and environmental performances [13-15].

All in all, there are many open issues in the literature regarding technical, logistical, economic and environmental aspects related to the sustainability of renewable energy from biomass; consequently, for this kind of energy, the sustainability cannot be taken for granted. In line with the above debate, this Special Issue contains original contributions that increase our comprehension of this topic.

\section{Form and Contents of the Thematic Issue}

The contributions of this Special Issue (Appendix A) mainly focus on the anaerobic digestion (AD) of agricultural feedstock paying attention to specific technical aspects (e.g., emissions, digestate valorization and price of the feedstock, etc.) as well as to the evaluation of the economic and environmental performances. In addition, the impact of biogas plant spreading in terms of landscape transformation is evaluated with regard to other biomass such as woody feedstock.

Regarding the biogas chain, Provolo et al. assessed global warming (GWP) and acidification potential (AP) for an agricultural anaerobic digestion plant in Northern Italy. The plant was a collective biogas plant fed with manure coming from 21 livestock units and it was equipped with a nitrogen removal system. Anaerobic digestion of slurry can be difficult due to the low methane potential, the low dry matter content and the consequently high transport cost. Furthermore, as highlighted by different studies [11] in small plants completely fed with slurry during the winter season the heating of the digesters at the process temperature can be difficult. However, for the collective plant evaluated the results were satisfactory; in fact, compare to the management of manure separately in different farms the evaluated system achieved a considerable impact reduction (52\% for GWP and $43 \%$ for AP).

Saracevic et al. conducted an economic and global warming potential (GWP) assessment of power generation with anaerobic digestion plants that focused on the Austrian biogas sector. The LCA approach was applied to the evaluation of the GWP. Twelve AD plants ranging from 150 to $750 \mathrm{~kW}$ were considered and for each of them different input material compositions were investigated. $66 \%$ of cogenerated heat was supposed to be used externally to substitute heat produced from fossil fuel while the digestate was considered as a substitute of mineral fertilizers. The results from the economic assessment revealed that the required additional payment (premium) to make the power generation economically viable ranges from 158.1-217.3 €/MWh. The GWP ranges from -0.42 to $+0.06 \mathrm{t} \mathrm{CO}_{2}$ eq./MWh and shows that the smaller plant configurations were the best performing with regard to this indicator. For all of the evaluated $\mathrm{AD}$ plants electricity from biogas in all scenarios outperformed the compared conventional electricity sources.

Borgonovo et al. focused attention on dairy slurry and on the possible mitigation of ammonia and greenhouse emissions using calcium sulfate dihydrate. Even if not directly connected to the generation of energy from biomass the study had some interest because the additive evaluated could also be applied on digestate. In fact, the emissions from digestate storage have been previously identified as an environmental hotspot [13-16].

Przywara et al. focused attention on digestate, the slurry resulting after the fermentation process. In this study, the authors compared two fertilization schemes of rapeseed with mineral fertilizers or with digestate in order to determine the static strength of seeds.

Csikos et al., using the density of anaerobic plants, evaluated the transformation of agricultural landscape due to bioenergy production. In the study hypothesis, the increasing use of biogas, produced from energy crops such as maize for silage, was supposed to noticeably change the structures and patterns of agricultural landscapes in Europe. Considering Northern Germany and via kernel density analysis impact zones which represent different levels of bioenergy-generated transformations of agrarian landscapes were delineated. For the period 2000-2012 significant correlations between the installed electrical capacity and the land cover changes were identified together with a reduction of pastures in favor of cropland. Concluding the authors underlined that a kernel density map of the 
installed capacity of biogas power plants might offer a suitable first indicator for monitoring and quantifying landscape change induced by biogas production.

Szulecka's study refers specifically to woody biomass. Among the different biomass, wood biomass is now widely seen as an important element in the efforts to tame dangerous climate change. In this context, the study investigated the relation between sustainability and the rapid technological growth that the woody biomass energy sector is facing. The article draws on a critical literature review to identify four different levels of sustainability in the existing research on bioenergy from wood and identified two solutions. The first one involves a top-down approach that draws on global forestry governance instruments, while the second one refers to a bottom-up approach using best-practice in forest plantations for bioenergy purposes. In the study a case study for Paraguay was reported, which combined economic, environmental and social aspects.

Attard et al. evaluated the regional biomass availability in Spain (Andalusia) and Ireland using a bioresource mapping model. The study outcomes support regional stakeholders with preliminary figures at regional opportunities with regards to feedstock availability and an estimate of the transportation costs. The authors highlighted how while considerable feedstock divergence existed within the regions, the mapping model could act as an effective tool for collecting and interpreting the regional data on a transnational basis.

Dong investigated the relationship between oil prices and maize prices, especially considering the influence of developing and producing bioenergy. Theoretical and empirical analyses were applied and the main findings were that: oil prices had a positive impact on maize prices, the development of bioenergy made the relationship between oil prices and maize prices closer without seriously affecting the maize prices, and the impact of oil prices on maize prices had a threshold, which was the profit gained when using maize to produce bioenergy.

In Almutairi et al., the economic, social and environmental impacts of renewable and nuclear energy targets for global electricity generation by 2030 were investigated. Different regions were considered (Saudi Arabia, the United States, China, India, Europe and the Rest of World) and two scenarios were evaluated: the business as usual (BAU) scenario assumes that the current electricity mix remains unchanged until 2030 and the Renewable and Nuclear Energy (RNE) scenario based on the International Energy Outlook (IEO) 2016 prediction. According to the analysis carried out by the authors the GDP was negatively affected by the shifting to RNE but the implementation of planned renewable and nuclear energy involves environmental benefits.

Finally, the study performed by Chen et al. evaluated the impact of foreign and indigenous innovations on the energy intensity of China's industries. The industrial energy intensity in 34 industrial sectors between 2000 and 2010 was analyzed in detail. The foreign innovations involve a decline in industrial energy intensity; on the other hand, exports ramped up the industrial energy intensity.

Funding: This research received no external funding.

Conflicts of Interest: The author declares no conflict of interest.

\section{Appendix A List of Contributions}

1. Almutairi, K.; Thoma, G.; Durand-Morat, A. Ex-Ante Analysis of Economic, Social and Environmental Impacts of Large-Scale Renewable and Nuclear Energy Targets for Global Electricity Generation by 2030. Sustainability 2018, 10, 2884, doi:10.3390/su10082884.

2. Attard, J.; McMahon, H.; Doody, P.; Belfrage, J.; Clark, C.; Ugarte, J.A.; Pérez-Camacho, M.N.; Martín, M.D.S.C.; Morales, A.J.G.; Gaffey, J. Mapping and Analysis of Biomass Supply Chains in Andalusia and the Republic of Ireland. Sustainability 2020, 12, 4595, doi:10.3390/su12114595.

3. Borgonovo, F.; Conti, C.; Lovarelli, D.; Ferrante, V.; Guarino, M. Improving the Sustainability of Dairy Slurry by a Commercial Additive Treatment. Sustainability 2019, 11, 4998, doi:10.3390/su11184998. 
4. Chen, S.; Du, X.; Huang, J.; Huang, C. The Impact of Foreign and Indigenous Innovations on the Energy Intensity of China's Industries. Sustainability 2019, 11, 1107, doi:10.3390/su11041107.

5. Csikos, N.; Schwanebeck, M.; Kuhwald, M.; Szilassi, P.; Duttmann, R. Density of Biogas Power Plants as An Indicator of Bioenergy Generated Transformation of Agricultural Landscapes. Sustainability 2019, 11, 2500, doi:10.3390/su11092500.

6. Dong, Z. Does the Development of Bioenergy Exacerbate the Price Increase of Maize? Sustainability 2019, 11, 4845, doi:10.3390/su11184845.

7. Moiceanu, G.; Paraschiv, G.; Voicu, G.; Dinca, M.; Negoita, O.; Chitoiu, M.; Tudor, P. Energy Consumption at Size Reduction of Lignocellulose Biomass for Bioenergy. Sustainability 2019, 11, 2477, doi:10.3390/su11092477.

8. Provolo, G.; Mattachini, G.; Finzi, A.; Cattaneo, M.; Guido, V.; Riva, E. Global Warming and Acidification Potential Assessment of a Collective Manure Management System for Bioenergy Production and Nitrogen Removal in Northern Italy. Sustainability 2018, 10, 3653, doi:10.3390/su10103653.

9. Przywara, A.; Kachel, M.; Koszel, M.; Leszczyński, N.; Kraszkiewicz, A.; Anifantis, A.S. The Influence of Digestate on the Static Strength of Spring Rapeseeds (Brassica napus var. arvensis). Sustainability 2019, 11, 2133, doi:10.3390/su11072133.

10. Saracevic, E.; Koch, D.; Stuermer, B.; Mihalyi, B.; Miltner, A.; Friedl, A. Economic and Global Warming Potential Assessment of Flexible Power Generation with Biogas Plants. Sustainability 2019, 11, 2530, doi:10.3390/su11092530.

11. Szulecka, J. Towards Sustainable Wood-Based Energy: Evaluation and Strategies for Mainstreaming Sustainability in the Sector. Sustainability 2019, 11, 493, doi:10.3390/su11020493.

\section{References}

1. Ingrao, C.; Bacenetti, J.; Bezama, A.; Blok, V.; Goglio, P.; Koukios, E.G.; Lindner, M.; Nemecek, T.; Siracusa, V.; Zabaniotou, A.; et al. The potential roles of bio-economy in the transition to equitable, sustainable, post fossil-carbon societies: Findings from this virtual special issue. J. Clean. Prod. 2018, 204, 471-488. [CrossRef]

2. Fusi, A.; Bacenetti, J.; Fiala, M.; Azapagic, A. Life Cycle Environmental Impacts of Electricity from Biogas Produced by Anaerobic Digestion. Front. Bioeng. Biotechnol. 2016, 4, 153. [CrossRef] [PubMed]

3. Knopf, B.; Nahmmacher, P.; Schmid, E. The European renewable energy target for 2030-An impact assessment of the electricity sector. Energy Policy 2015, 85, 50-60. [CrossRef]

4. Talagai, N.; Marcu, M.V.; Zimbalatti, G.; Proto, A.R.; Borz, S.A. Productivity in partly mechanized planting operations of willow short rotation coppice. Biomass Bioenergy 2020, 138, 105609. [CrossRef]

5. Borz, S.A.; Nita, M.D.; Talagai, N.; Scriba, C.; Grigolato, S.; Proto, A.R. Performance of Small-Scale Technology in Planting and Cutback Operations of Short-Rotation Willow Crops. Trans. ASABE 2019, 62, 167-176. [CrossRef]

6. Negri, M.; Bacenetti, J.; Manfredini, A.; Lovarelli, D.; Fiala, M.; Maggiore, T.M.; Bocchi, S. Evaluation of methane production from maize silage by harvest of different plant portions. Biomass Bioenergy 2014, 67, 339-346. [CrossRef]

7. Samarappuli, D.; Berti, M. Intercropping forage sorghum with maize is a promising alternative to maize silage for biogas production. J. Clean. Prod. 2018, 194, 515-524. [CrossRef]

8. Bacenetti, J.; Sala, C.; Fusi, A.; Fiala, M. Agricultural anaerobic digestion plants: What LCA studies pointed out and what can be done to make them more environmentally sustainable. Appl. Energy 2016, 179, 669-686. [CrossRef]

9. González-García, S.; Bacenetti, J. Exploring the production of bio-energy from wood biomass. Italian case study. Sci. Total Environ. 2019, 647, 158-168. [CrossRef] [PubMed]

10. Bacenetti, J.; Fiala, M. Carbon Footprint of Electricity from Anaerobic Digestion Plants in Italy. Environ. Eng. Manag. J. 2015, 14, 1495-1502. [CrossRef]

11. Bacenetti, J.; Fusi, A.; Azapagic, A. Environmental sustainability of integrating the organic Rankin cycle with anaerobic digestion and combined heat and power generation. Sci. Total Environ. 2019, 658, 684-696. [CrossRef] [PubMed] 
12. Proto, A.R.; Bacenetti, J.; Macri, G.; Zimbalatti, G. Roundwood and bioenergy production from forestry: Environmental impact assessment considering different logging systems. J. Clean. Prod. 2017, 165, 1485-1498. [CrossRef]

13. Lovarelli, D.; Falcone, G.; Orsi, L.; Bacenetti, J. Agricultural small anaerobic digestion plants: Combining economic and environmental assessment. Biomass Bioenergy 2019, 128, 105302. [CrossRef]

14. Collet, P.; Flottes, E.; Favre, A.; Raynal, L.; Pierre, H.; Capela, S.; Peregrina, C. Techno-economic and Life Cycle Assessment of methane production via biogas upgrading and power to gas technology. Appl. Energy 2017, 192, 282-295. [CrossRef]

15. O'Keeffe, S.; Thrän, D. Energy Crops in Regional Biogas Systems: An Integrative Spatial LCA to Assess the Influence of Crop Mix and Location on Cultivation GHG Emissions. Sustainability 2019, 12, 237. [CrossRef]

16. Lijó, L.; González-García, S.; Bacenetti, J.; Negri, M.; Fiala, M.; Feijoo, G.; Moreira, M.T. Environmental assessment of farm-scaled anaerobic co-digestion for bioenergy production. Waste Manag. 2015, 41, 50-59. [CrossRef] [PubMed]

(C) 2020 by the author. Licensee MDPI, Basel, Switzerland. This article is an open access article distributed under the terms and conditions of the Creative Commons Attribution (CC BY) license (http://creativecommons.org/licenses/by/4.0/). 